J. Perinat. Med. 12 (1984) 75

\section{Maternal and fetal effects of low-dosage bupivacaine paracervical block}

\author{
J. Puolakka, R. Jouppila, P. Jouppila, M. Puukka
}

Departments of Obstetrics and Gynecology, Anesthesiology, and Clinical Chemistry, University of Oulu, Finland

\section{Introduction}

The etiology of fetal bradycardia following paracervical block (PCB) is not clear. Vasoconstriction of the uterine arteries, hypertonus of the uterus, and the direct toxic effect of a local anesthetic agent on the fetus or a combination of the above have been presented as etiological factors [17]. To reduce fetal side-effects, a superficial and low dosage technique has been advised by BLOOM [2] and JÄGERHORN [10]. By this method it may be possible to decrease the rate of the absorption of an anesthetic agent from the highly vascular paracervical space.

Since there is no consistent information about the maternal and fetal effects of this kind of PCB, we have studied the fetal heart rate patterns (FHR), uterine activity, placental blood flow, and fetal acid-base balance in connection with such a block. In addition, we measured the actual maternal, fetal and neonatal plasma bupivacaine levels.

\section{Materials and methods}

2.1 Patients: Thirty-eight patients, who had an uncomplicated pregnancy, were between the 39-41 weeks of gestation and in active labor with the fetus in cephalic presentation were studied. In three cases a second PCB was used approximately two hours after the first block, so the material number includes in total $41 \mathrm{PCBs}$. The age of the

\section{Curriculum vitae}

JUKKA PUOLAKKA was born on January 20, 1947 and obtained his medical degree in 1972 at the University of Oulu, Finland. Specialized in gynecology and obstetrics at the University of Oulu in 1979 and Ph. D. in 1980. He is currently a senior physician of the department of obstetrics and gynecology, University of Oulu, Finland.

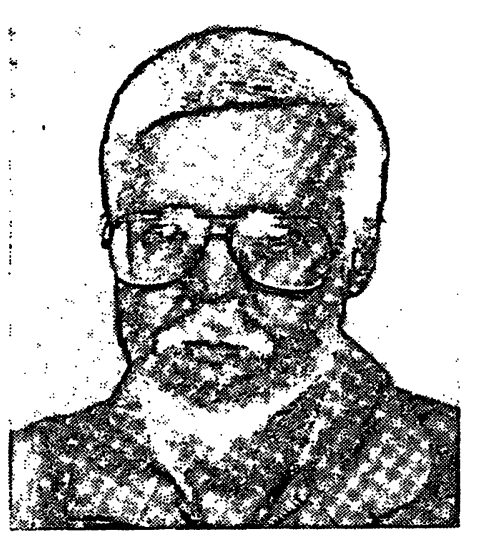

patients varied from 18 to 28 years (mean \pm SD, $24.3 \pm 3.7)$, and the parity from 1 to $3(1.6 \pm 0.5)$. The mean duration of the labor was 10 hours 52 minutes \pm 3 hours 37 minutes and the mean period from PCB to delivery 2 hours 24 minutes \pm 1 hour 19 minutes. The mean weight of the babies was 3,565 \pm 352 grams and all but one had APGAR scores of 8 or better at 1,5 and 15 minutes. The one exception was a baby who had $3 / 6 / 8$ scores at 1,5 and 15 minutes and was delivered by vacuum extraction because of bradycardia in the second stage of labor, 4 hours 32 minutes after PCB. Another baby was also delivered by vacuum extraction due to prolongation of the second stage 2 hours and 12 minutes after PCB but was in excellent condition after delivery. One cesarean section was performed 8 hours after PCB because of persistent occiput posterior presentation. 
2.2 Paracervical block: The block was performed when the patient had painful contractions and the cervix was dilated 4 to $7 \mathrm{~cm}$. During the procedure the patient was in the left lateral (tilted $30^{\circ}$ ) position, and after PCB she was turned into a totally lateral position. During and 30 minutes after the procedure, the patient received $500 \mathrm{ml}$ of RINGER solution. The patient's heart rate and blood pressure were recorded before the PCB and at three minutes intervals during the first 30 minutes after the block. Bupivacaine with a total dose of $10 \mathrm{ml}(25 \mathrm{mg})$ of $0.25 \%$ solution was used. Five $\mathrm{ml}$ of the solution was injected with a KOBAK's needle to each lateral fornix and the depth of the injection was limited to no more than $3 \mathrm{~mm}$.

2.3 Fetal heart rate (FHR) monitoring: At least 30 minutes before $\mathrm{PCB}$ the membranes were ruptured if not already ruptured, and the FHR of the fetuses were directly monitored using a scalp electrode during a control period of at least 20 minutes before PCB and thereafter until delivery. The details of the FHR pattern were analyzed visually. The decelerations were classified according to HON [7]. Baseline variability was evaluated by the maximum amplitudes for 1-minutes periods. An amplitude less than 5 beats per minute for more than 5 minutes was regarded as being of the silent type. Acceleration was defined as an increase of FHR from baseline by more than 15 beats in less than 30 seconds. Bradycardia was defined as a decrease of mean FHR of at least $20 \mathrm{bpm}$ or an absolute rate less then $100 \mathrm{bpm}$ and of a duration greater than two minutes. Baseline, baseline variability, the number of different decelerations (early, late, variable), accelerations and the occurrence and duration of bradycardia were determined for each 10-minute period during the 20 minute prior $\mathrm{PCB}$ and 30 minute after the block.

2.4 Uterine activity: In eleven patients the intrauterine pressure was measured using an openended transcervical intrauterine catheter connected to a strain gauge placed at the level of the sternum. In these patients the baseline uterine tone, frequency, and amplitude of contractions (measured in MONTEVIDEO units) were recorded during a 20 minute control period and 30 minute observation period after PCB. In other patients frequency and relative change in amplitude of contractions were measured by external tocography.

2.5 Placental blood flow: Both intervillous and myometrial blood flow was measured in ten patients with the placenta at the anterior wall of the uterus just before and 10 minutes after PCB. These patients remained in the tilted left laterally position from PCB until the second measurement. The placental blood flow in $\mathrm{ml} / \mathrm{min} / 100 \mathrm{ml}$ of the intervillous space was measured by ${ }^{133} \mathrm{Xe}$-washout method described in detail elsewhere [15].

2.6 Bubivacaine concentrations: Blood samples for the determination of the plasma bupivacaine concentration were taken from a maternal vein and the fetal scalp 20 minutes after PCB and at delivery from a maternal vein and the umbilical artery and vein. The plasma bupivacaine concentrations were measured with a specific gas-liquidchromatographic method [11].

2.7 Fetal acid-base balance: A fetal scalp sample and umbilical venous and arterial blood samples were obtained in 14 cases. The actual $\mathrm{pH}$ was immediately determined according to the method of SALING just before the $\mathrm{PCB}$ and 15 to 20 minutes after PCB and at delivery.

2.8 Statistics: STUDENT's t-test and Chi-Squaretest were used for the statistical analyses of the results.

\section{Results}

3.1 Maternal effects: The analgesic effect of a single $\mathrm{PCB}$ as assessed by the patients was good in 31 cases (76\%), "moderately good" in 5 cases $(12 \%)$, and "poor" in 5 cases $(12 \%)$. The duration of the PCB varied from one to two hours. The maternal heart rate was $80 \pm 11 \mathrm{bpm}$ before and $85 \pm 7$ after the PCB on average. Systolic blood pressure was correspondingly $131 \pm 21 \mathrm{mmHg}$ and 
Tab. I. Changes in fetal heart rate pattern before and after paracervical block with $25 \mathrm{mg}$ of bupivacaine $(\mathrm{N}=41)$

\begin{tabular}{|c|c|c|c|c|c|}
\hline & $\begin{array}{l}\text { Control perio } \\
\text { before block } \\
-20 \mathrm{~min}\end{array}$ & $10 \mathrm{~min}$ & $\begin{array}{l}\text { Observation } \\
\text { after block } \\
+10 \mathrm{~min}\end{array}$ & $\begin{array}{l}\text { period } \\
+20 \mathrm{~min}\end{array}$ & $+30 \mathrm{~min}$ \\
\hline Basal rate, bpm (mean $\pm S D)$ & $132 \pm 10$ & $132 \pm 11$ & $127 \pm 21$ & $129 \pm 21$ & $134 \pm 12$ \\
\hline Variability, bpm & $14 \pm 5$ & $15 \pm 4$ & $14 \pm 5$ & $11 \pm 5^{*}$ & $13 \pm 5$ \\
\hline Disappearance of FHR accelerations ( $\mathrm{n}$ : of patients) & 1 & 0 & 4 & $11 * * *$ & $6 * *$ \\
\hline Bradycardia & $\mathbf{0}$ & 0 & $4 * *$ & 2 & 0 \\
\hline Silent pattern & $\mathbf{0}$ & 0 & 2 & $5 * *$ & 2 \\
\hline Early or variable decelerations $(<30 \mathrm{bpm})$ & 15 & 17 & 17 & 20 & 19 \\
\hline Early or variable decelerations ( $>30 \mathrm{bpm}$ ) & 0 & 1 & $6^{*}$ & 3 & 1 \\
\hline Late decelerations & 0 & 0 & $4^{*}$ & $5 * *$ & 1 \\
\hline
\end{tabular}

$*=p<0.05$

$* *=\mathrm{p}<0.01\}$ vs. control period (t-test or $\mathrm{X}^{2} \cdot$ test)

$* * *=p<0.001\}$
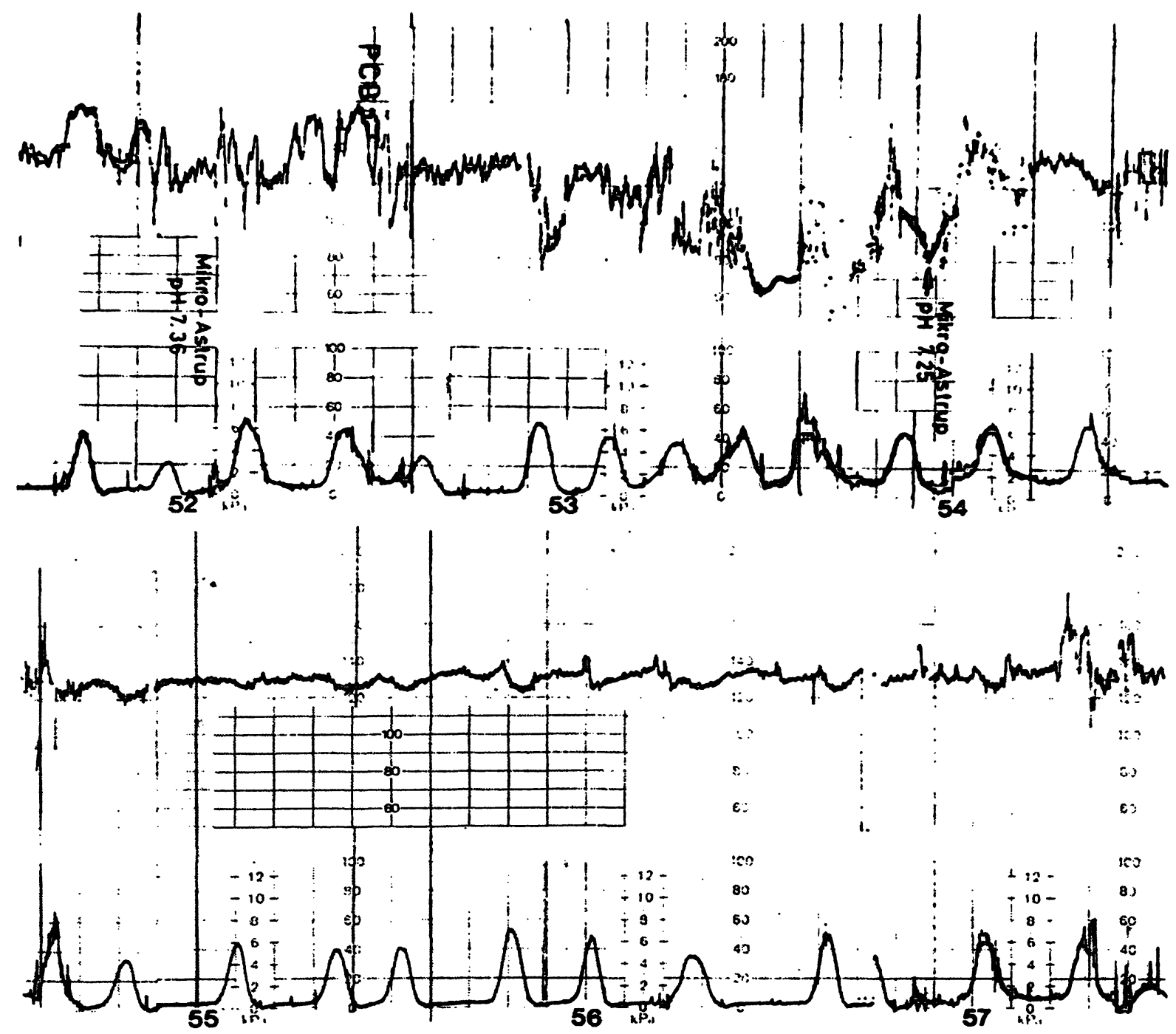

Fig. 1. An example of the fetal bradycardia and acidosis following paracervical block. Note the apparent increase in uterine tone and loss of beat-to-beat variation after the bradycardia episode. 
diastolic $82 \pm 15 \mathrm{mmHg}$ before PCB and $125 \pm 20$ and $82 \pm 11$ after PCB ( $p>0.05)$. No cases of hypotension (fall of the blood pressure by $20 \%$ or more) were recorded and no local or systemic side-effects of bupivacaine were observed.

3.2 Fetal heart rate pattern: The results are summarized in Tab. I

The mean basal fetal heart rate during the 10 minute periods did not change significantly. The baseline fetal heart rate variability decreased significantly during the period from 10 minutes through 20 minutes after PCB. Recordings without FHR accelerations were noticed only once during the control period but 11 times $(27 \%)(\mathrm{p}<0.001)$ during the second and 6 times $(15 \%)(p<0.01)$ during the third observation period after PCB. Bradycardia was not observed during the control period but appeared in $12 \%$ of the cases $(p<0.01)$ after PCB. One case demonstrating fetal bradycardia is presented in Fig. 1. Fetal heart rate decelerations of early or variable type more than $30 \mathrm{bpm}$ appeared significantly $(\mathrm{p}<0.05)$ more often during the first observation period than during the control time. Late decelerations (4 and 5 during the first and second observation periods, respectively) occurred only after PCB. No cases of silent pattern were noticed during the control period but appeared in $20 \%$ of the cases after the block $(\mathrm{p}<0.05)$.

3.3 Bupivacaine concentrations: Mean maternal bupivacaine concentration 20 minutes after PCB was $0.14 \pm 0.06 \mathrm{ug} / \mathrm{ml}$ and $0.07 \pm 0.04$ at birth . Simultaneous fetal, umbilical venous and arterial concentrations were correspondingly $0.04 \pm 0.02$, $0.03 \pm 0.01$ and $0.03 \pm 0.01 \mathrm{ug} / \mathrm{ml}$ and they were significantly $(\mathrm{p}<0.001)$ lower than the respective maternal concentrations. Individual maternal and fetal concentrations and their changes at 20 minutes after PCB and at delivery are shown in Figs. 2, 3 and 4. One episode of bradycardia occurred in these eleven cases (indicated in Fig.4).

3.4 Placental blood flow: The mean myometrial blood flow was $9.0 \pm 5.0$ before and $10.4 \pm 9.0 \mathrm{ml} /$ $\mathrm{min} / 100 \mathrm{~g}$ after PCB. Mean intervillous flow (IVBF) was $128 \pm 63$ and $146 \pm 61 \mathrm{ml} / \mathrm{min} / 100 \mathrm{ml}$

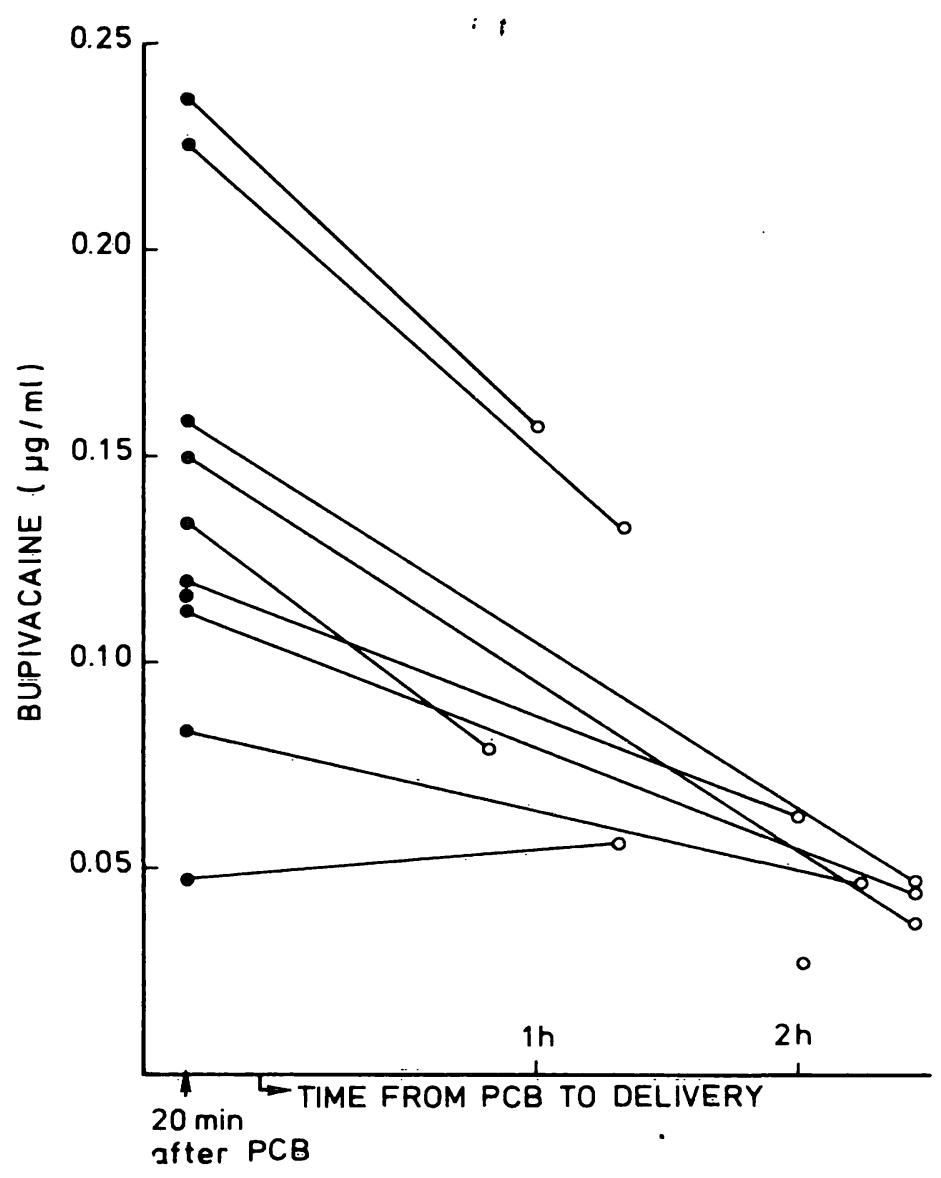

Fig. 2. Maternal plasma bupivacaine concentrations after paracervical block with $25 \mathrm{mg}$ of bupivacaine. Closed circles represent values 20 minutes after the block and open circles values at delivery.

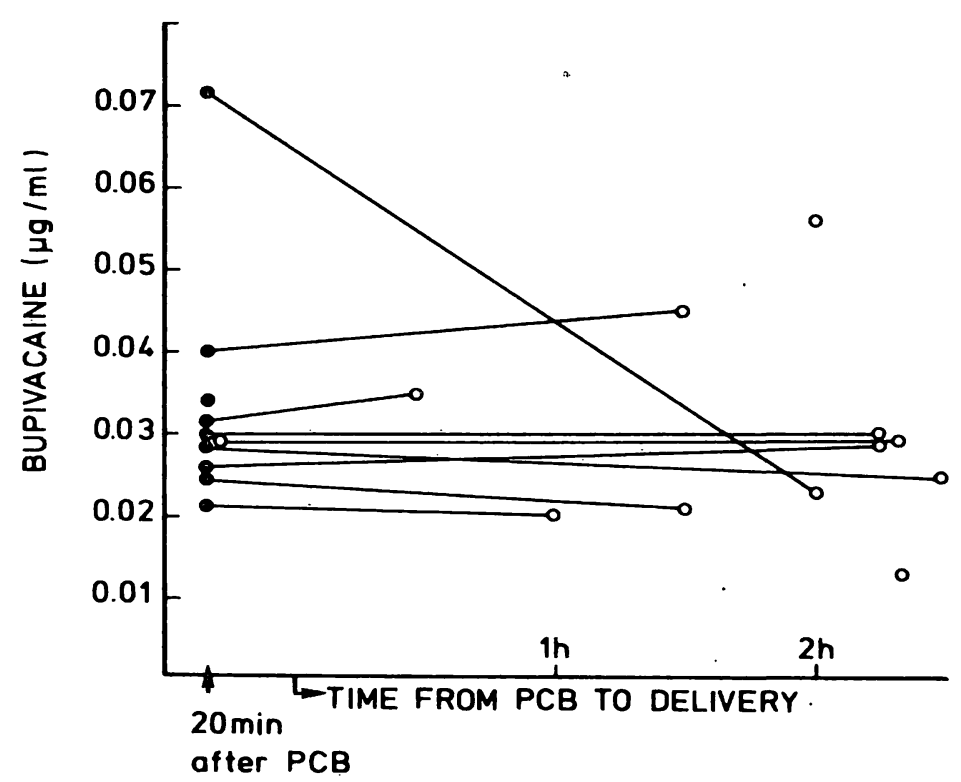

Fig. 3. Fetal plasma levels of bupivacaine after paracervical block with $25 \mathrm{mg}$ of bupivacaine. Closed circles represent concentrations in fetal scalp blood 20 minutes after the block and open circles concentrations in umbilical artery blood. 


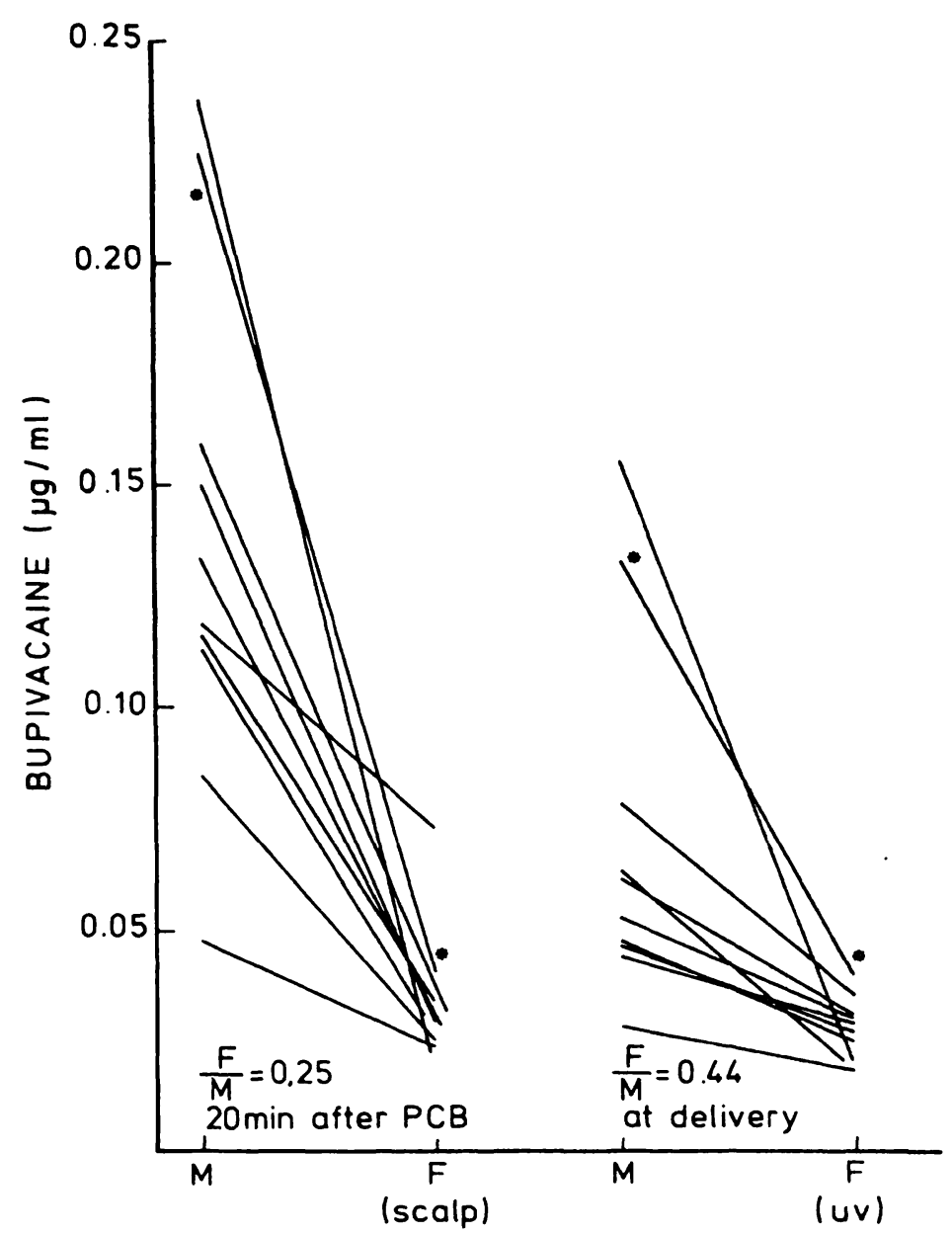

Fig. 4. Correlation of maternal and fetal bupivacaine levels 20 minutes after PCB and at delivery. The asterix indicates one case with fetal bradycardia.

respectively $(\mathrm{p}>0.05)$. Individual measurements are shown in Fig. 5 in which three cases with pathological FHR pattern are illustrated. The changes in the IVBF were minimal in these cases also.

3.5 Uterine activity: No significant changes in uterine tone, amplitude and frequency of contractions were observed after PCB. Mean Montevideo units were $155 \pm 12$ before and $150 \pm 20,152 \pm 12$, $165 \pm 15$ during the three ten minute-periods after PCB ( $p>0.05$ ). An obvious hypertonus of the uterus after PCB was observed in three cases of bradycardia but not in the other two cases of bradycardia, in the eight cases of silent FHR pattern or in nine cases of late decelerations.

3.6 Fetal acid-base balance: Mean actual fetal $\mathrm{pH}$ from the scalp capillary blood just before PCB was $7.33 \pm 0.05$ and $7.31 \pm 0.0320$ minutes after
IVBF

$\mathrm{ml} / \mathrm{min} / \mathrm{dl}$

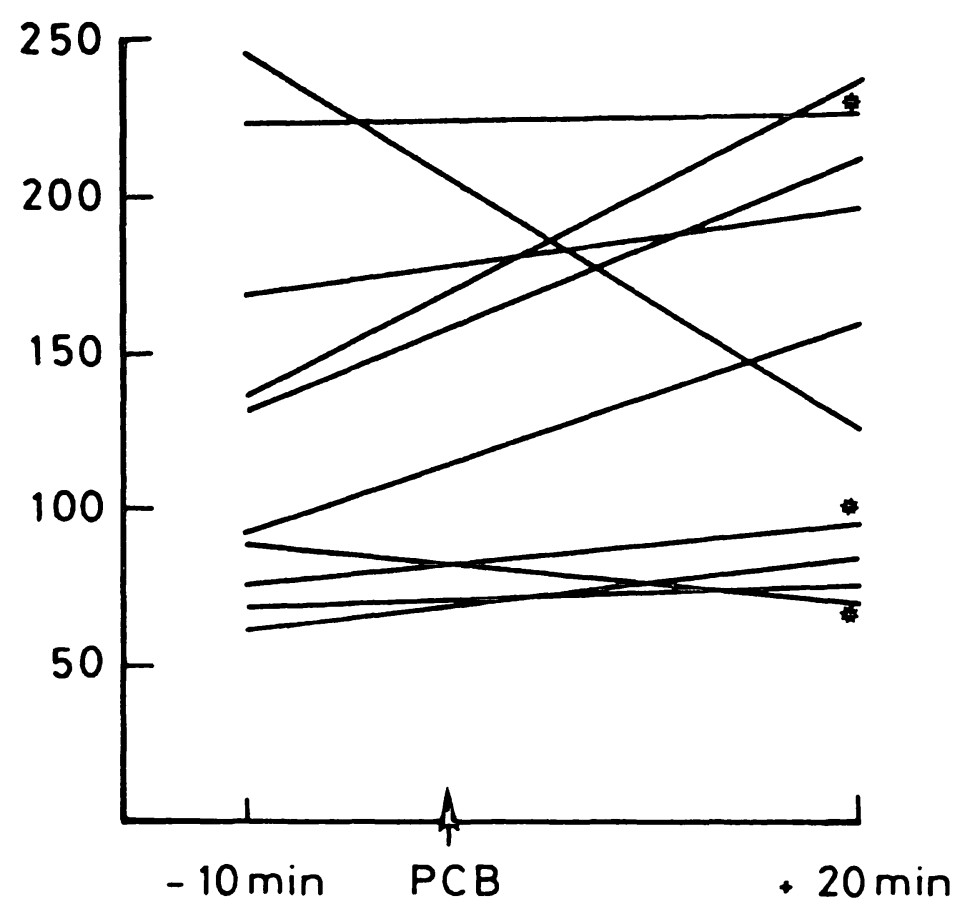

Fig. 5. Intervillous blood flow as measured by 133 Xenon washout method before and after paracervical block with $25 \mathrm{mg}$ of bupivacaine. The asterix indicate cases with fetal bradycardia.

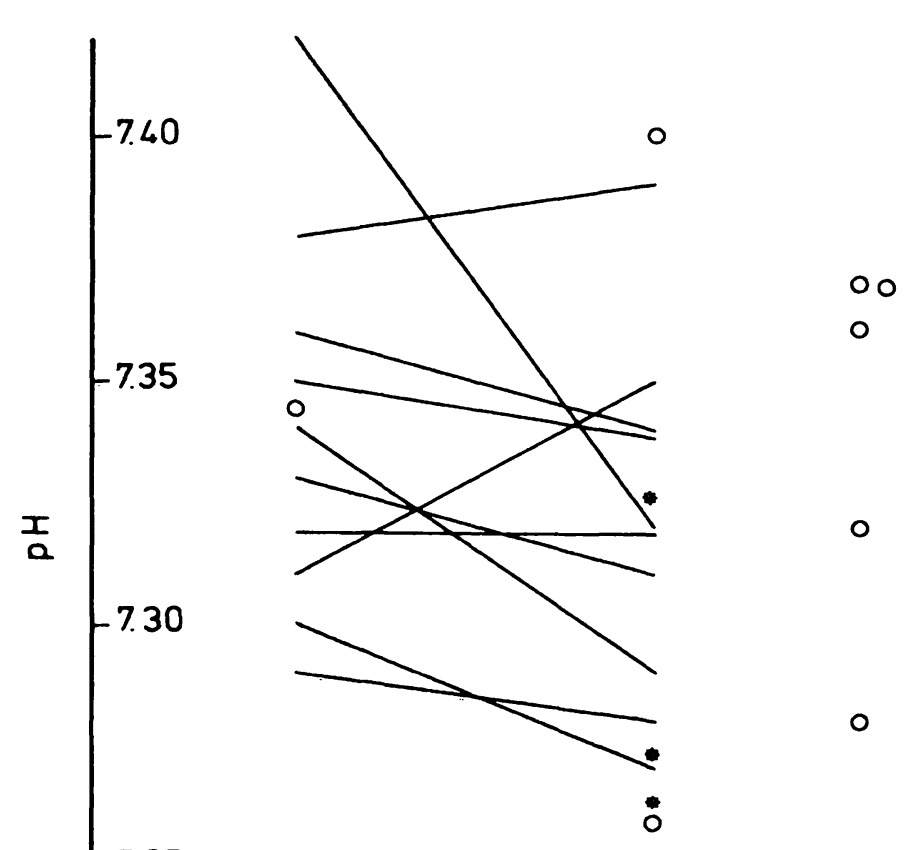

$-7.25$

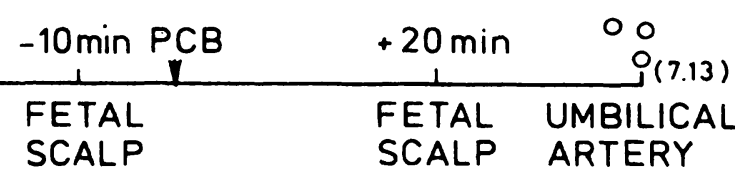

Fig. 6. The actual pH in fetal scalp before and after $P C B$ and in umbilical artery immediately after delivery. The asterix indicate cases with fetal bradycardia. 
PCB ( $\mathrm{p}>0.05)$. Individual fetal scalp $\mathrm{pH}$ values as well as mean umbilical arterial values ( 2 hours 20 minutes after PCB) are shown in Fig. 6. In three cases of bradycardia the mean fetal $\mathrm{pH}$ was 7.28 after PCB. Mean $\mathrm{pH}$ from umbilical venous blood was $7.27 \pm 0.08$ and arterial blood $7.36 \pm 0.09$.

\section{Discussion}

In spite of extensive clinical experience and research work, the usefulness and safety of PCB is still a matter of controversy $[9,17]$. To reduce fetal hazards, a low dosage, superficial technique of PCB has been advised by BLOOM [2] and by JÄGERHORN [10] and was also used in our study. The success rate $(76 \%)$ and the failure rate $(12 \%)$ we found using that technique are of a similar order to that reported when using larger bupivacaine dosages [17]. The plasma levels of bupivacaine after low dosage $(25 \mathrm{mg})$ administration in maternal, fetal and neonatal blood are lower than reported by HYMAN [8] (maternal 0.14, neonatal $0.08 \mathrm{ug} / \mathrm{ml})$ or by BEAZLEY [1] (1.07 and 0.10), who used $50 \mathrm{mg}$ of bupivacaine at PCB. No results of plasma bupivacaine concentration in connection with the present low dosage PCB have been published. On the other hand, in connection with epidural analgesia using $25 \mathrm{mg}$ of bupivacaine correspondingly low levels have been observed [11]. The maternal-fetal ratios of bupivacaine after PCB or at delivery are in our results very similar to earlier studies using bupivacaine in PCB $[1,8]$ or in epidural blocks [11]. Thus, it thus seems possible to decrease fetal and maternal levels of bupivacaine by using a low dosage and by superficial injection technique without loss of any of the analgesic effect.

Despite reduced fetal bupivacaine levels, several significant changes in the FHR occurred after PCB in the present series. In the whole group about one-third of the blocks were associated with noticeable changes. Our results do not agree with some earlier studies reporting lack of FHR changes after low dosage PCB $[10,12,14]$. Bradycardia lasting on average for 8 minutes and starting $2-4$ minutes after PCB was observed at a $12 \%$ rate. TERAMO [16], by using $100 \mathrm{mg}$ or $50 \mathrm{mg}$ of bupivacaine, found a $21 \%$ frequency of bradycardia, HoLLMEN [6] a rate of $30 \%$, JÄGERHORN [10] a $10 \%$ rate but MEIS [12] and REID [14] almost none. Comparison of FHR patterns after PCB are difficult because most earlier studies have not been done with direct FHR recording and also the criteria of pathological and non-pathological FHR patterns, e.g. bradycardia are not unambiguous. Late decelerations in our study were observed in five cases after PCB and mostly in association with bradycardia as also noted in earlier reports [16]. Decreased FHR variability (silent pattern) was observed after $20 \%$ of the blocks which corresponds to the findings of MEIS et al. [12]. The most frequent change in FHR after PCB in our material was the disappearance of FHR accelerations. The accelerations have been regarded as a sensitive sign of fetal arousal level and nonhypoxic state $[7,13]$. Similar finding was also reported by MEIS [12].

The fetal $\mathrm{pH}$ did not decrease on average after PCB but the fall was more pronounced in 3 cases with bradycardia which is in accordance with the findings of previous studies [16]. No universal change in the mean uterine activity was noticed after PCB, but in five cases demonstrating bradycardia three showed a prompt increase in uterine contractions and in the baseline tone, which might at least partly explain the change in the FHR pattern.

The etiopathology of FHR changes in connection with PCB is obviously multifactorial [17]. According to our observations the most important factor in these mechanisms seems to be the rapid transplacental passage of the local anesthetic agent into the fetal circulation. Since we were not able to show any decrease in placental blood flow after PCB even in cases of fetal bradycardia, the initial bradycardia obviously represents a direct toxic effect of bupivacaine on the fetal heart and on its regulatory centers. In vitro experiments using uterine artery pieces show $[3,4]$ that lidocaine can constrict these vessels for a considerable time, when much higher concentrations $(400-1000 \mathrm{ug} / \mathrm{ml})$ than seen in clinical practice are used. Extrapolation of these results in vivo conditions seems to be hardly applicable to human studies. In ewes a direct injection of bupivacaine 
into the maternal aorta bringing about a plasma concentration of $5 \mathrm{ug} / \mathrm{ml}$ results in hypertonus of the uterus, fetal bradycardia and decreased uterine blood flow [5]. These plasma concentrations are very high and in the interpretation of these animal studies it is difficult to determine which of the parameters is the primary one. Disappearance of FHR accelerations and decrease of FHR variability observed in our study represent a direct pharmacological effect of bupivacaine at fetal level. These kinds of changes are commonly seen after administration of many other drugs used in labor, e.g. pethidin (meperidine) [13]. Although there is obviously some relation between pathological FHR and fetal plasma concentration of the agent, the most important factor may still be the pharmacokinetic properties of the anesthetic agent, i.e. the rate of the rise of fetal drug concentration after the block. Our universal observation was that mothers with fetal bradycardia very rapidly achieved analgesia after PCB. The superficial injection technique was initially developed to reduce rapid absorption of the local anesthetic agent from the paracervical space. It seems possible that even after carefully applied blocks a rapid absorption of the drug may sometimes occur leading to an abrupt rise in blood concentrations and to fetal FHR changes. This observation may signify that the technique of PCB must be individually modified. Probably the best method to avoid rapid absorption is according to our recent experience, to maintain an interval of 10-15 minutes between the application of anesthetic solution to each side of the cervix.

\section{Summary}

Vasoconstriction of the uterine arteries, hypertonus of the uterus, and the direct toxic effects of a local anesthetic on the fetus or a combination of the above have been presented as etiological factors of fetal bradycardia following paracervical block. The reduce fetal sideeffects a superficial and lowdosage technique of PCB have been advocated. We have studied the effects of $25 \mathrm{mg}$ of bupivacaine PCB using the above technique on fetal heart rate pattern (FHR), fetal acid-base balance, uterine activity, placental blood flow and maternal and fetal plasma levels of bupivacaine in 38 patients.

The analgesic effect of a single $25 \mathrm{mg}$ of bupivacaine PCB was good in $76 \%$, moderate in $12 \%$ and poor in $12 \%$ of the cases. No changes in maternal heart rate or in blood pressure were noted. Fetal bradycardia defined as a decrease of mean fetal heart rate of at least $20 \mathrm{bpm}$ or an absolute rate less than $100 \mathrm{bpm}$ and a duration greater than two minutes occurred in $12 \%$ of the cases. The mean amplitude of the baseline fetal heart rate variability decreased significantly after PCB and a silent pattern (an amplitude less than $5 \mathrm{bpm}$ ) was observed in $20 \%$ of the cases. The most frequent $(27 \%)$ pathological finding in our study was the disappearance of FHR accelerations after PCB. Similarly early and late decelerations of FHR occurred more often after PCB than during the control period before the block. The fetal pH from scalp blood samples did not, on avarage, decrease after PCB, but did so in cases with fetal bradycardia.

Intervillous blood flow as measured by the ${ }^{133} \mathrm{Xe}$ washout method did not change when measured before and after PCB. In addition in three cases with fetal bradycardia the changes in the intervillous blood flow were minimal. No significant changes in the mean uterine tone, amplitude and frequency of contractions were observed after PCB. However, an obvious uterine hypertonus was observed after PCB was observed in three cases of fetal bradycardia but not in two other cases of bradycardia or in the 8 cases of silent FHR pattern.

Mean maternal bupivacaine concentration 20 minutes after PCB was $0.14 \pm 0.06 \mathrm{ug} / \mathrm{ml}$ and $0.07 \pm 0.04 \mathrm{ug} / \mathrm{ml}$ at birth. Simultaneous fetal and umbilical venous and arterial concentrations were correspondingly $0.04 \pm 0.02 \mathrm{ug} / \mathrm{ml}$, $0.03 \pm 0.01 \mathrm{ug} / \mathrm{ml}$ and $0.03 \pm 0.01 \mathrm{ug} / \mathrm{ml}$, and they were significantly lower than respective maternal concentrations.

It seems possible to decrease fetal and maternal levels of bupivacaine by using a low dosage and superficial injection technique without loosing anything of the analgesic effect. However, several significant changes in fetal heart rate pattern can occur. About one third of the block were associated with noticable FHR changes in the present series. The etiopathology of FHR changes in connection with PCB is obviously multifactorial. According to our observations the most important factor in these mechanisms seems to be the rapid transplacental passage of the local anesthetic into fetal circulation. Since we were not able to show any decrease of placental blood flow after PCB even in cases with fetal bradycardia, the initial bradycardia obviously represents a direct toxic effect of bupivacaine on the regulatory centers of the fetal heart rate. Disappearance of FHR accelerations and the decrease of FHR variability observed in our study represent a pharmacological effect of bupivacaine at fetal level. In some cases uterine hypertonus following PCB may be an additional etiological factor of fetal bradycardia.

It seems possible that even after carefully applied PCBs a rapid absorption of the local anesthetic agent may sometimes occur leading to an abrupt rise in the fetal blood concentrations and to fetal heart rate changes.

Keywords: Bupivacaine, paracervical block, fetal heart rate pattern, fetal pH, placental blood flow, plasma levels of bupivacaine, uterine activity. 


\section{Zusammenfassung}

Wirkungen eines Paracervicalblocks mit Bupivacain in niedriger Dosierung auf Mutter und Fet

Als ätiologische Faktoren einer fetalen Bradykardie nach einem paracervikalen Block (PCB) werden die Vasokonstriktion der uterinen Arterien, ein erhöhter Tonus des Uterus, direkte toxische Wirkungen der lokalen Anästhesie oder eine Kombination aller drei Effekte angesehen. Durch eine oberflächliche Injektion einer niedrigen Dosis glaubt man, die fetalen Nebenwirkungen beim PCB reduzieren zu können. Wir untersuchten die Wirkung eines PCB mit $25 \mathrm{mg}$ Bupivacain, in oben beschriebener Technik appliziert, auf die fetale Herzfrequenz (FHR), den fetalen Säure-Basen-Status, die Uterusaktivität sowie die Plazentadurchblutung und bestimmten die mütterlichen und fetalen Bupivacain-Plasmaspiegel. Das Untersuchungskollektiv bestand aus 38 Patientinnen.

Die analgesierende Wirkung eines PCB mit einer einzelnen Bupivacaindosis von $25 \mathrm{mg}$ war bei $76 \%$ der Fälle gut, bei $12 \%$ mäßig und bei weiteren $12 \%$ schlecht. Die mütterliche Herzfrequenz sowie der Blutdruck blieben unverändert. Eine fetale Bradykardie, definiert als ein Abfall der mittleren Herzfrequenz um mindestens $20 \mathrm{bpm}$ oder eine absolute Frequenz von weniger als $100 \mathrm{bpm}$ bei einer Dauer von mehr als 2 Minuten, ereignete sich in $12 \%$ der Fälle. Die mittlere Amplitude der basalen FHR-Variabilität nahm nach dem PCB signifikant $a b$; silente Verläufe (Amplitude unter $5 \mathrm{bpm}$ ) wurden in $20 \%$ der Fälle beobachtet. Der häufigste pathologische Befund (27\%) in unserer Untersuchung war das Sistieren der FHRAkzelerationen nach dem PCB. Ebenso fanden sich Früh- und Spätdezelerationen der FHR nach dem PCB häufiger als in der Kontrollphase vor dem Block. Der fetale $\mathrm{pH}$ im Skalpblut zeigte im Schnitt keinen Abfall nach dem PCB; ein Abfall erfolgte jedoch bei den Feten mit Bradykardien.

Die Durchblutung im intervillösen Raum, gemessen mit der ${ }^{133} \mathrm{Xe}$-Auswaschmethode, zeigte nach dem PCB keine Veränderung gegenüber der Kontrolle vorher. Es muß aber hinzugefügt werden, daß in 3 Fällen mit fetaler Bradykardie minimale Veränderungen des intervillösen Blutflusses registriert werden konnten. Hinsichtlich der mittleren Tonisierung des Uterus sowie der Amplitude und
Häufigkeit der Kontraktionen haben wir keine signifikanten Veränderungen nach dem PCB beobachtet. Jedoch ließ sich in 3 Fällen mit fetaler Bradykardie ein deutlich gesteigerter uteriner Tonus feststellen, während in 2 weiteren Fällen mit Bradykardie sowie in 8 Fällen mit silenten FHR-Mustern diese Veränderung ausblieb.

Die mittlere Bupivacain-Konzentration im mütterlichen Blut betrug 20 Minuten nach dem PCB 0,14 $\pm 0,06 \mu \mathrm{g} / \mathrm{ml}$ und zum Zeitpunkt der Geburt 0,07 $\pm 0,04 \mu \mathrm{g} / \mathrm{ml}$. Simultane Messungen im fetalen Blut sowie im venösen und arteriellen Nabelblut ergaben Konzentrationen von $0,04 \pm 0,02 \mu \mathrm{g} / \mathrm{ml}, 0,03 \pm 0,01 \mu \mathrm{g} / \mathrm{ml}$ und $0,03 \pm 0,01 \mu \mathrm{g} / \mathrm{ml}$ und lagen damit signifikant niedriger als die mütterlichen Konzentrationen.

Es scheint möglich zu sein, die fetalen und mütterlichen Bupivacainspiegel durch eine niedrige Dosis und eine oberflächliche Injektionstechnik zu senken, ohne die analgesierende Wirkung $\mathrm{zu}$ reduzieren. Jedoch können einige wichtige Veränderungen des FHR-Musters auftreten. In unserer Untersuchungsreihe war ein Drittel der Blocks mit ernstzunehmenden FHR-Veränderungen assoziiert, deren Ätiologie im Zusammenhang mit dem PCB offensichtlich multifaktoriell ist. In Übereinstimmung mit unseren Beobachtungen wird der rasche transplazentare Transport des Lokalanästhetikums in den fetalen Kreislauf als der wichtigste Faktor angesehen. Da wir selbst bei fetalen Bradykardien nach dem PCB keine herabgesetzte Plazentadurchblutung nachweisen konnten, ist die initiale Bradykardie offensichtlich Folge eines direkten toxischen Effektes des Bupivacains auf die Regulationszentren des fetalen Herzens. Das Sistieren der FHR-Akzelerationen sowie der Abfall der FHR-Variabilität, die wir in unserer Untersuchung beobachtet haben, spiegeln die pharmakologische Wirkung auf fetalem Niveau wieder. In einigen Fällen mag der gesteigerte uterine Tonus ein zusätzlicher ätiologischer Faktor bei der fetalen Bradykardie sein.

Offensichtlich kann selbst nach sorgfältig gesetzen PCB's manchmal eine rasche Resorption des Lokalanästhetikums erfolgen, die dann zu einem,plötzlichen Anstieg des fetalen Bupivacain-Spiegels und damit zu FHR-Veränderungen führt.

Schlüsselwörter: Bupivacain, Bupivacain-Spiegel, fetale Herzfrequenz, fetaler pH, paracervikaler Block, Plazentadurchblutung, Uterusaktivität.

\section{Résumé}

Effets du bloc para-cervical à la bupivacaïne à faible dose sur la mère et le fœtus

On a incriminé la vasoconstriction des artères utérines, l'hypertonie utérine, et les effets toxiques directs sur le fœtus d'une anesthésie locale ou l'association de ces éléments comme facteurs étiologiques de la bradycardie fœtale survenant après bloc para-cervical. On a proposé une technique de BPC superficiel et à faible dose afin de réduire les effets secondaires sur le fœtus. Nous avons étudié les -effets du bloc para-cervical effectué selon la technique ci-dessus avec $25 \mathrm{mg}$ de bupivacaïne sur le rythme cardiaque fœtal (RCF), l'équilibre acido-basique fœtal, l'activité utérine, le débit sanguin placentaire et les concentrations plasmatiques fœtales et maternelles de bupivacaïne chez 38 patientes.

L'effet analgésique d'un BPC utilisant 1 dose unique de $25 \mathrm{mg}$ de bupivacaïne a été bon dans $76 \%$ des cas, moyen dans $12 \%$ et faible dans $12 \%$. On n'a pas mis en évidence de modifications de la fréquence cardiaque maternelle ni de la pression artérielle. Dans $12 \%$ des cas est survenue une bradycardie fœtale, définie par une diminution pendant au moins 2 minutes du rythme cardiaque fœtal 
moyen d'au moins $20 \mathrm{bpm}$ ou une fréquence absolue inférieure à $100 \mathrm{bpm}$ pendant au moins 2 minutes. L'amplitude moyenne de l'instabilité de base du rythme cardiaque fœtal diminue de façon significative après BPC et un rythme plat (avec une amplitude inférieure à $5 \mathrm{bpm}$ ) s'observe dans $20 \%$ des cas. L'élément pathologique le plus fréquent $(27 \%)$ trouvé dans notre étude est la disparition des accélérations du RCF après BPC. De même, des décélérations précoces et tardives du RCF surviennent plus souvent après BPC que durant la période témoin avant le bloc. Le $\mathrm{pH}$ fœtal analysé à partir de prélévements au scalp ne diminue pas en moyenne après BPC, mais chute en cas de bradycardie fœtale. Le débit sanguin intervilleux déterminé par la méthode de dilution au $133 \mathrm{Xe}$ ne subit pas de modification s'il est mesuré avant et après BPC. De plus, dans 3 cas de bradycardie fœtale, les modifications du débit sanguin intervilleux ont été minimes. On n'a pas observé de modifications significatives du tonus utérin de base, ni dans l'amplitude et la fréquence des contractions utérines après BPC. Cependant, une hypertonie utérine réelle a été observée après $B P C$ dans 3 cas de bradycardie fœtale mais non dans les 2 autres cas de bradycardie ni dans les 8 cas de rythmes plats.

Les concentrations maternelles moyennes de bupivacaïne ont été de $0,14 \pm 0,06 \mathrm{ug} / \mathrm{ml} 20$ minutes après $\mathrm{BPC}$ et de $0,07 \pm 0,04 \mathrm{ug} / \mathrm{ml}$ à la naissance. Les concentrations simultanées fœtales et ombilicales correspondantes (artérielles et veineuses) étaient de $0,04 \pm 0,02 \mathrm{ug} / \mathrm{ml}$; $0,03 \pm 0,01 \mathrm{ug} / \mathrm{ml}$ et de $0,03 \pm 0,01 \mathrm{ug} / \mathrm{ml}$, ce qui est significativement inférieur aux concentrations maternelles correspondantes.

Il semble possible de diminuer les taux maternels et fœtaux de bupivacaine en utilisant de faibles doses et une technique d'injection superficielle sans perdre en analgésie. Néanmoins, plusieurs modifications significatives du rythme cardiaque fœtal peuvent se produire. Environ 1/3 des blocs se sont accompagnés de modifications notables du RCF dans cette série. L'étiopathologie des modifications du RCF en liaison avec le BPC est objectivement multifactorielle. Selon nos observations, le facteur le plus important dans ces mécanismes semble être le passage transplacentaire rapide de l'anesthésique local dans la circulation fœtale. Toutefois, il ne nous a pas été possible de montrer une diminution du flux sanguin placentaire après BPC même lors de bradycardies fœtales, la bradycardie initiale représente objectivement un effet toxique direct de la bupivacaïne sur les centres régulateurs du rythme cardiaque fœtal. La disparition des accélérations et la diminution de l'instabilité du RCF observées dans notre étude sont le témoin d'un effet pharmacologique de la bupivacaïne aux taux fœtaux. Dans quelques cas, l'hypertonie utérine après BPC peut être un facteur étiologique supplémentaire de la bradycardie fœtale.

Il semble possible que même après un BPC réalisé avec soin, une absorption rapide du produit anesthésique local puisse parfois se produire entrainant une élévation brutale des concentrations sanguines fœtales et des modifications du rythme cardiaque fotal.

Mots-clés: Activité utérine, bloc para-cervical, bupivacaïne, débit sanguin placentaire, $\mathrm{pH}$ fœtal, rythme cardiaque fœtal, taux plasmatiques de bupivacaïne.

\section{Bibliography}

[1] BEAZLEY, J., G. TAYLOR, R. REYNÖ̈DS: Placental transfer of bupivacaine after paracervical block. Obstet. and Gynec. 39 (1972) 2

[2] BLOOM, S., W. HORSWILL, L. CURET: Effects of paracervical blocks on the fetus during labor: A prospective study with the use of direct fetal monitoring. Am. J. Obstet. Gynecol. 114 (1972) 218

[3] CIBILS, L.: Response of human uterine arteries to local anesthetics. Am. J. Obstet. Gynecol. 126 (1976) 202

[4] GIBBS, C., S. NOEL: Human uterine artery response to lidocaine. Am. J. Obstet. Gynecol. 126 (1976) 313

[5] GREISS, F., G. STILL, S. ANDERSON: Effects of local anesthetic agents on the uterine vasculature, and myometrium. Am. J.Obstet. Gynecol.124 (1976) 889

[6] HOllmen, A., M. KORHONEN, A. OJAlA: Bupivacaine in paracervical block-Plasma levels and changes in maternal and foetal acid-base balance. Br. J. Anaesth. 41 (1969) 603

[7] HON, E. H.: An introduction to fetal heart rate monitoring. New Haven, CT 1973

[8] HYMAN, M., S. SHNEIDER: Maternal and neonatal blood concentrations of bupivacaine associated with obstetrical conduction anesthesia. Anesthesiology 34 (1971) 81

[9] JACOBSON, L.: Paracervical blockade during labor. Rev. Perinat. Med. 2 (1978) 143

[10] J ÄGERHORN, M.: Paracervical block in obstetrics. An improved injection method. Acta Obstet. Gynecol. Scand. 54 (1975) 9

[11] JOUPPILA, R., P. JOUPPILA, L. KOTINIEMI, J. PUOLAKKA, R. PUUKKA: Maternal and foetal plasma bupivacaine concentrations in labour with segmental epidural analgesia. Ann. Chir. Gynaecol. 67 (1978) 190

[12] MEIS, P., L. REISNER, 'T. PAYNE, C. HOBEL: Bupivacaine paracervical block. Effects on the fetus and neonate. Obstet. Gynecol. 52 (1978) 545

[13] PETRIE, R., S. YEH, Y. MURATA, R. PAUL, E. HON, B. BARRON, R. JOHNSON: The effect of drugs on fetal heart rate variability. Am. J. Obstet. Gynecol. 130 (1978) 294

[14] READ, J., F. MILLER: The bupivacaine paracervical block in labor and its effect on quantitative uterine activity. Obstet. and Gynec. 53 (1979) 166

[15] REKONEN, A., H. LUOTONEN, M. PITKÄNEN, J. KUIKKA, T. PYÖRÄL ̈̈: Measurement of inter- 
villous blood flow by an intravenous 133 Xe method. Received July 15, 1983. Accepted September 9, 1983. Br. J. Obstet. Gynecol. 83 (1976) 723

[16] TERAMO, K.: Fetal acid-base balance and heart rate during labour with bupivacaine paracervical block anaesthesia. J. Obstet. Gynaec. Brit. Cwlth. 76 (1969) 881

[17] THIERY, M., S. VROMAN: Paracervical block analgesia during labor. Am. J. Obstet. Gynecol. 113 (1972) 988

J. Puolakka,

Department of Obstetrics and Gynecology. University-of Oulu,

90220 Oulu 22, Finland 